\title{
Career Guidance Shortages in Indonesian Vocational High School
}

\author{
Imam Mahir ${ }^{1}$, Thomas Köhler ${ }^{2}$, Soenarto ${ }^{3}$, and Slamet PH ${ }^{3}$ \\ ${ }^{1}$ Vocational Education of Mechanical Engineering Study Program, Jakarta State University, \\ Indonesia \\ ${ }^{2}$ Institute of Vocational Education, Technische Universitat Dresden, Germany \\ ${ }^{3}$ Graduate School Program, Yogyakarta State University, Indonesia
}

\section{Abstract}

Career guidance as an integral part of national education system plays a prominent role in vocational education to facilitate the students in achieving their self-reliance. The discussion on their relationship raises stimulating evidence of weaknesses in its practice in Indonesian vocational high school. This article highlights the substance of career guidance shortages and the implications from its tradition. Thorough analysis shows that career guidance should be simultaneous with vocational education

Corresponding Author: Imam Mahir

imammahirunj@gmail.com

Received: 11 January 2019 Accepted: 14 February 2019 Published: 25 March 2019

Publishing services provided by Knowledge E

(c) Imam Mahir et al. This article is distributed under the terms of the Creative Commons

Attribution License, which permits unrestricted use and redistribution provided that the original author and source are credited.

Selection and Peer-review under the responsibility of the 3rd ICTVET 2018 Conference Committee.

\section{G OPEN ACCESS} programs to prepare graduates who are standing by to employ. The shortages of career guidance in vocational high school means a small portion, non-stipulated of achievement standards, and hardly congenial to vocational education characteristics. The revitalization act, labor market and skills trends, and career pathways affiliate to the necessity of particular career guidance in vocational high school. It should be noted that specificity of career guidance in vocational high school is aimed to strengthen the employability skills development.

Keywords: career guidance, vocational education, employability skills

\section{Introduction}

Some of the Indonesian government's policies on vocational education are unable to respond issues notably related to unemployment. For instance, a policy by Minister of Education and Culture (MoEC) came up in an early 21st century for increasing the quantity of Vocational High School (VHS) by the proportion $70 \%$ for VHS and 30\% for General High School (GHS) with aim chiefly to reduce the number of unemployment. However, by analysis of the statistics from 2004 - 2014, it is showing different explanation. The number of unemployed VHS graduates in 2014 increased in comparison to data in 2004 [1]. Accordingly, this policy has not succeeded to gain to what expected. The problems appeared on the misconnection between producing skilled workforce in VHS and working opportunities in the world of work. 
To explain the problem on unemployment, the review on career guidance practice in VHS is harmless. Because the notion of career guidance is dwelt in issues on employment, occupation, job, work, and abilities to employ. Career guidance assists clients to find out their potentials to get work or to endeavor other career opportunities. It is crucial to reviews career guidance as one of major determinant factor the unemployment problem. A study shows that among the causes of employment problems are job search behavior [2].

Earlier approaches did already focus on inter-sectoral integration of efforts, overarching labor market information stakeholders as well as vocational training stakeholders and others. One example is the European project "Network for Career Guidance in Schools", an international and intersectoral approach funded by the European Union (cf. http://www.career-guide.eu). While the Career Guide brought together experts in pedagogy, psychology, technology and labour market, all of them dealt with promoting career guidance practices in European schools. The target group was designed around pupils up to K12 age, including professionals like counsellors, teachers specialized in career guidance and policy makers [3].

A more recent German effort is the complete recording and presentation of current and regular projects, measures, initiatives and actors of the professional and study orientation in the German state capital Dresden [4]. This project developed empirical evidence that even though there is a large number of specified measures career guidance practices designed to assist especially young people around the intersection between school and labour market it is especially challenging to select and apply appropriate measures form such a variety.

Another effort reducing the number of unemployment, the Indonesian Ministry of Manpower offers the training programs regularly, providing occupational information on the Employment Service Center (ESC) and placing workforce. For graduates education or job seekers who willing to enhance their competency could pursue training in vocational training centers (Balai Latihan Kerja/BLK). The ESC is an online job fair provides information and job opportunities offering by the companies. To bridge the gap between training program and labor market information the prominent role of career guidance is considerable necessitated. Moreover, preliminary interview with some fresh graduates in Indonesia showed that generally lack of prior career information leads to career problem [5].

On the other hand, the ministry of education and culture (MoEC) also provides education and training in vocational high school (VHS) to prepare workforce who ready to work with specific job skills. The problem comes up when missing connection between 
education and training program among ministries. For example, the job opportunities expanding program by the Ministry of Manpower is not well-informed to vocational schools. The role of career guidance is also to support education and training by providing information about what the training program preferred and the skills needed.

This review will underscore the unique functions of career guidance in VHS in comparison to general high school (GHS). It will identify the philosophical problem and misconnection between career guidance and vocational education. Some official sources such as Law, government regulation, minister regulation, and manual book are used to draw the concept and to analysis the problem. Scientific sources from fundamental theory, research findings, and other scientific studies are helpful to affirm the argumentation. The final result of the analysis will be concluded and some recommendations will be proposed.

\section{A Review the Concept of Career Guidance and Vocational Education}

\subsection{Theory review on career guidance}

In the field of guidance and counseling is well-known the three-terms of educational guidance, career guidance, and vocational guidance. Experts are partially difference to view these three concepts. One part holds that they are a unified concept. Other are more likely to use career guidance in place of vocational guidance term. Some writers in the field of vocational education and training are maintaining the term vocational guidance or differently such as vocational advice and vocational aspiration. The author, in this case, proposes a glossary established by the National Vocational Guidance Association in the United State written by Sear. Career guidance can be defined as those activities and program assist individual to assimilate and integrate knowledge, experience, and appreciations to address related to: (1) self-understanding; (2) understanding of the world of work; (3) awareness of the part leisure time; (4) sense of the necessity for and the multitude of factors to be considered in career planning; (5) comprehension of the information and skills necessary to achieve self-fulfillment in work and leisure; (6) learning and applying the career decision-making process [6].

On the other hand, vocational guidance has a close relationship to career guidance. Vocational guidance is self-concept oriented and concentrates primarily on selfunderstanding and self-acceptance, to which can be associated the educational and vocational alternatives available to the individual [6]. Then, vocational guidance deals 
with matters of occupational choice or career planning, preparation, placement, and adjustment on the job [7]. Also, Miller emphasized that vocational guidance is being subsumed under the broader concept of career guidance [8]. Based on experts, vocational guidance can be defined as a guiding process for the individual to attain his/her goal regarding career and uncertainty about a job in the future.

Since vocational education working on producing graduates who well-prepared to employ, the career guidance should also be treated differently from general education. Based on curriculum VHS, at the beginning of entering school at a very young stage of development, students have required to make decisions or career plans. This condition will allow the emergence of problems such as students feeling misplaced study program, unable to adapt themselves to the courses taken, feeling unsuited to their aptitude and interests. Also, in the second year, VHS students must also follow the Industrial Work Practice program that requires the ability to adapt to the workplace environment. At that young stage of development, they need guidance to ready to enter the workplace.

\subsection{Practical career guidance in the Indonesian secondary schools}

The practical guidance and counseling in Indonesian schools are officially ruled by the Ministry of Culture and Education (MoEC). At level secondary school, the MoEC establishes the newest two manual books in 2016 which for GHS and VHS respectively. Table 1 explains the obvious comparison practical guidance and counseling between GHS and VHS. According to these Manual Books, by comparison, the program of guidance and counseling in GHS and VHS are almost identical. The difference between two manuals is lain on the specialization objective of programs which focusing on selecting in a group subject matter for GHS and grouping interest on the field of expertise for VHS. The discussion about what implications from this comparison will be in next section.

\subsection{Relationship between career and vocational education}

Career and vocational education terminologies has discussed in many studies around the world. The attention to this is particularly strong for two explanations that the terms tends to puzzle the closer relations between the two thoughts and the propensity to consider that career guidance is mostly disjointed to vocational education [9]. Therefore, the relationship between these two terms necessitate to be explained based on expert 
TABLE 1: Comparison Practical Guidance and Counseling Program between GHS and VHS.

\begin{tabular}{|c|c|c|}
\hline \multirow{2}{*}{$\begin{array}{l}\text { Guidance and Counseling } \\
\text { Program }\end{array}$} & \multicolumn{2}{|c|}{ Practical on Manual Book } \\
\hline & GHS & VHS \\
\hline $\begin{array}{l}\text { Understanding aspects of } \\
\text { students" characteristic }\end{array}$ & $\begin{array}{l}\text { physical, cognitive, social, } \\
\text { emotion, morals, religious }\end{array}$ & $\begin{array}{l}\text { physical, cognitive, social, } \\
\text { emotion, morals, religious }\end{array}$ \\
\hline $\begin{array}{l}\text { Understanding of students } \\
\text { techniques }\end{array}$ & test and non-test technique & test and non-test technique \\
\hline $\begin{array}{l}\text { Components of guidance and } \\
\text { counseling services }\end{array}$ & $\begin{array}{l}\text { essential, responsive, individual } \\
\text { planning and specialization, } \\
\text { support system }\end{array}$ & $\begin{array}{l}\text { essential, responsive, individual } \\
\text { planning and specialization, } \\
\text { support system }\end{array}$ \\
\hline $\begin{array}{l}\text { Fields of guidance and } \\
\text { counseling services }\end{array}$ & $\begin{array}{l}\text { personal, learning, social, and } \\
\text { career }\end{array}$ & $\begin{array}{l}\text { personal, learning, social, and } \\
\text { career }\end{array}$ \\
\hline Direct services & $\begin{array}{l}\text { counseling, guidance, } \\
\text { consultation, collaboration, } \\
\text { referral, home visit, advocacy, } \\
\text { case conference }\end{array}$ & $\begin{array}{l}\text { counseling, guidance, } \\
\text { consultation, collaboration, } \\
\text { referral, home visit, advocacy, } \\
\text { case conference }\end{array}$ \\
\hline Specializations & $\begin{array}{l}\text { selection and determination } \\
\text { interests group on subject } \\
\text { matters }\end{array}$ & $\begin{array}{l}\text { selection and determination } \\
\text { interests group on field of } \\
\text { expertise }\end{array}$ \\
\hline
\end{tabular}

reviews and other reports. On the other hand, vocational education and training define as training in the skills, the related knowledge, and the social sense for a specific job or groups of associated job [6].

Early efforts in career guidance chiefly centered on job placement of school leavers and unemployed youth who lacked a marketable skill in a labor market where skill was becoming a necessity. Because of this situation, the initial proponent of vocational education concentrated on the marketable skills development and ignored vocational guidance [7]. However, this condition has changed over time along with the increasingly significant role of career guidance. As Miller stated that guidance is a crucial component of vocational education [8]. Furthermore, career guidance principles and practice are linked to its quality and effectiveness at two diverse stages: before entering and within the vocational education and training (VET) program [9].

\subsection{A review of practical career guidance among other countries}

Many developed countries are investing in vocational and career guidance because of the utilities they have performed over time [10]. Over the past two decades, in the European community, career guidance has already been seen as an essential element in the European Communities into two move programs on the transition from childhood to adult and school to working life [11]. The role of guidance is crucial because it is located at the junction where challenges converge. These problems confront policy-makers 
who are planning to accomplish the objectives of lifelong learning, social well-being, employment and economic development [12].

There are various model of career guidance practice among European countries. The comprehensive model is already described by Watts et al. [11]. However, the short compendium of this career guidance principle and practice as follows: (1) there is definite distinction between educational and vocational guidance, these being allocated to totally separate agencies (notably Germany); (2) the traditions are particularly based within educational institution (e.g. Denmark, Ireland); (3) the methods are primarily found in separate agencies which service educational system (e.g. Belgium, France, Italy, and Luxembourg); (4) the practice is especially based within official labor-market organizations (e.g. Germany).

Unlike many other countries, Germany has the model of guidance which is classified into two-model responsibility. Corresponding to Deutsche model there is strict partition responsibility sphere between educational and vocational guidance. Thus, the two service concepts are developed in different ways and face dissimilar problems as well [13]. The distinctive roles of educational and vocational guidance in Germany are originated in its federal education system which is portrayed by walling up the secondary school (i.e. Gymnasiums, Fach-gymnasien, Fachober-schulen, Berufs- fachschulen, Duales-System, Berufs-ausbauschulen) and of tertiary education (i.e. higher education such as: Universitäten, Fach-schulen, Abend-schulen and Kollegs). At school as well as at university level, the educational guidance is operated. Meanwhile, the Federal Employment Institute (FEI) is the exclusive agency responsible for vocational guidance. It means that other institutions are proscribed from providing vocational guidance including schools and universities [13]. The two model role of guidance in Germany can be seen in Table 2 .

Vocational guidance service, in Germany, is established as such separated from the general education and the vocational training system as well as from the Federation of industry, crafts, and commerce. Vocational guidance in Germany can be offered only by the Federal Employment Institute, which also operates vocational information centers in many states [11]. Therefore, the link between vocational guidance and vocational education and training (VET) that they are interlinked and mutually supportive. The task of vocational guidance service comprises vocational orientation, vocational counseling, obtaining apprenticeships, and promoting professional training [13].

In low- and middle-income countries, moreover, emerging scheme in career guidance linked to VET are frequently stimulated with support from international donors. Such promising examples from Georgia, Chile, Serbia, Kosovo, and the Former Yugoslav 
TABLE 2: Two model role of guidance in Germany.

\begin{tabular}{|c|c|c|}
\hline $\begin{array}{l}\text { Aspects of Guidance } \\
\text { Service }\end{array}$ & Educational Guidance & Vocational Guidance \\
\hline Principles & $\begin{array}{l}\text { Americans" philosophy on } \\
\text { educational and vocational guidance }\end{array}$ & $\begin{array}{l}\text { To aid economy to cover its } \\
\text { workforce demand }\end{array}$ \\
\hline Task & $\begin{array}{l}\text { Helping in vertical and horizontal } \\
\text { permeability of educational career }\end{array}$ & $\begin{array}{l}\text { Assisting people to realize a free } \\
\text { occupational choice. }\end{array}$ \\
\hline Field & $\begin{array}{l}\text { School career, individualized } \\
\text { guidance and counseling, parent } \\
\text { counseling, innovation in } \\
\text { educational system }\end{array}$ & $\begin{array}{l}\text { Vocational orientation, vocational } \\
\text { counseling, obtaining } \\
\text { apprenticeship, promoting } \\
\text { professional training. }\end{array}$ \\
\hline Governmental body & $\begin{array}{l}\text { Under jurisdiction of the individual } \\
\text { states }\end{array}$ & $\begin{array}{l}\text { Subordinate to the Federal } \\
\text { Employment Office }\end{array}$ \\
\hline $\begin{array}{l}\text { Professional and } \\
\text { assistant staff }\end{array}$ & $\begin{array}{l}\text { School counsellors, school } \\
\text { psychologists, and student advisors. }\end{array}$ & $\begin{array}{l}\text { Vocational counsellors, rehabilitation } \\
\text { counsellors, apprenticeship officer. }\end{array}$ \\
\hline $\begin{array}{l}\text { Organizational } \\
\text { structure }\end{array}$ & $\begin{array}{l}\text { At school and university level clearly } \\
\text { differ. }\end{array}$ & $\begin{array}{l}\text { Centralized and authorized by the } \\
\text { Federal authorities. }\end{array}$ \\
\hline
\end{tabular}

Republic of Macedonia present practical model of career guidance in developing countries. Unfortunately, its implementation poses some challenges, notably about sustainability. Practice shows that local ownership, local authorities, and embedded-ness in broader national strategies are integral to the survival of projects as well as for the further systemic development of career guidance. In the end, an approach which fosters demand, rather than supply-driven career guidance provision, and a local strategy will be more likely to be successful both before and within VET [14].

\section{The Need of Career Guidance in Indonesian Vocational School}

\subsection{Revitalization of vocational high school}

The government has issued the Presidential Directive Number 9 the Year 2016 on the revitalization of vocational high schools. The Presidential Instruction aims to improve the synergy between stakeholders, the relevant ministries, national agency, and governors to revitalize VHS to enhance the quality of Indonesian human resources. Based on this instruction the president instructed the Ministers, the head of the National Agency for Profession Certification, and the governors to succeed revitalization and to compile a map of the workforce needs of vocational graduates [15]. Thus, the government has realized the importance of vocational education to prepare skilled and productive human resources. This revitalization means restoring the primary function and strengthening the role of VHS to produce graduates who are ready to work. However, its program 
should also be succeeded by the improvement of the career guidance program to strengthen connectivity and synchronization of government programs.

\subsection{Understanding labor market system}

Effective vocational education is determined by how it affords to produce graduates who have capabilities to achieve career in the work society. In this case, VHS graduates are required to have the ability to recruit the right career decisions which are awareness of the work environment in which the occupations and jobs become available, the working conditions, the benefits offered by the job, and so on. Thus, they must thoroughly understand the labor market system. It cannot be neglected that labor market conditions and trends continue to evolve and change according to the demands of the times and the world of work.

Career guidance plays the role to meet VHS students with specific queries related to the labor market and allied sectors of education and training. It is a mechanism how career guidance matches the supply and demand of worker on labor market system. The labor market for this purpose is composed of: workers in various industries or the government, employers including private and government organizations, selfemployed or partially employed persons, unemployed and those who are in the process of entering the labor market [16].

\subsection{The need of developing $21^{\text {st }}$ Century's skills}

The vocational education curriculum should be emphasized on the developing longterm outcomes characteristics and guiding students to be able to face challenges about uncertainty work and their careers in the future. It is primarily concern with the attainment of knowledge and skills for the world of work for individual career development and social economic improvement [17]. Besides, the VET curriculum must also be judged regarding its graduates' success. The success standards can be indicated by achieving skills such as effective job skills, technical skills, occupational survival skills, job search skills, and entrepreneurial skills [17]. These success standards should be simultaneous with the developing student's career in the VET institution.

To prepare the VHS graduates having the quality as the world of work expected can be achieved by providing career guidance for students to have abilities for working and to improve performance for learning. Learning process in the 21st century should meet the primary skills such as critical thinking and problem solving, creativity and 
innovation, collaboration, teamwork, and leadership, cross-cultural understanding, communications, information, and media literacy, computing and ICT literacy, career and learning self-reliance [18]. Those skills are corresponding on the part of such generic employability skills in the vocational education curriculum. The study mentions that one part of most essential skills in vocational education curriculum are initiative and enterprises skills, personal organization and time management skills, self-awareness and self-learning skills, problem- solving and adaptability skills [19]. The concept of school as a career development center emphasizes on how vocational education institution can be optimized for developing employability skills as the work societies demanded. This idea is come from the situation about what the world of work demands to their employees" ability. In the workplace environment today, employees have to be able to be „self-directing,' that can rule their own tasks, take the initiatives and make the proper decisions when needed [20].

\section{Model of Career Guidance in Vocational High School}

\subsection{Linkages of developmental tasks and independence competence learners standards}

The developmental tasks is a series of tasks must be accomplished by the students in a specific life period or developmental phase [21]. It comes from physical maturity, psychological maturity, community or cultural demands and individual values and aspirations. The success of students to accomplish it will make them feeling happy and to be their capital for completing the next phase of developmental tasks. Conversely, the failure of students to achieve it will make them disappointed and underestimated others. This failure of it will be tough for the students to complete the tasks or inhibiting the next phase of development. It is one aspect that must be understood by school counselors because their achievement is the target of guidance and counseling services. Guidance and counseling services are one form of facilitating students to achieve developmental tasks. The developmental tasks of VHS students can be seen in Table 2.

The Graduates Competency Standards (GCS) of learners in high school formulated on MoEC Regulation Number 54/2013 must be achieved by learners through the process of learning at various subjects. However, the MoEC Regulation Number 54/2013 is only assigning the GCS for learning activities. Unfortunately, this regulation does not state the standards for guidance and counseling for students" achievement. Therefore, the Indonesian Counseling and Guidance Association (ICGA) takes the initiative to formulate 
TABLE 3: The Linkage of Developmental Task and Aspect in LSCS.

VHS Students' Developmental Task
Achieving the development of self as a teenager who
believes and cautious to God Almighty
Recognize the ethical system and values for the guidelines
of life as individuals, members of society, and human
interests.
Recognize and develop attitudes about emotional, social,
and economic self-reliance.
Develop knowledge and skills following their needs to
follow and continue the lesson and prepare for a career
and play a role in community life.
Establishing acceptable values and ways of behaving in
broader social life
Achieving a good relationship pattern with peers in the
role of men or women.
Prepare, receive and be positive and dynamic about the
physical and psychological changes that occur to oneself
for a healthy life.
Have the independence of economic behavior
Recognize the abilities, talents, interests, and direction of
career tendency and art appreciation
Achieving maturity of relationships with peers
Achieve maturity in the readiness of self-married and
family life.

Developmental Aspects of LSCS
The foundation of religious life
The basis of ethical behavior
Emotional maturity
Intellectual maturity
Awareness of social responsibility
Gender awareness
Self-development
Entrepreneurial behavior
Career insight and readiness
The maturity of relationships with
peers
Preparedness to marry and have
family

the Competency Standards to be achieved by students, from elementary to higher education levels. In academic forms, it is important to set the provision to serve a practical guidelines and as the consideration of the Ministry of National Education in determining the policy of guidance and counseling services in Indonesia.

Table 2 describes the relationship between two standards. Hence, the term for learning activities standard is called the Graduate Competency Standards (GCS), while the standard for guidance and counseling is known as the Learners Self-Reliance Competency Standards (LSCS) which includes eleven aspects of individual development particularly for secondary school and university level. The students" developmental task identifies students" needs to be further developed in the form of competency standards (LSCS). The various developmental aspects in LSCS are basically associated to the developmental tasks to be achieved by students. Thus, between the developmental tasks and development aspects in LSCS has a very close relationship.

MoNEC regulation Number 111/2014 on Article 6 states that guidance and counseling in the high school level comprise four field of service: personal, learning, social, and career [22]. It also consists of four primary programs: basic service, individual planning and specialization, responsive service, and support system service [22]. The discussion 
and elaboration will be on the field of career guidance services. Figure 1 below is described career guidance model based on MoNEC regulation and some VHS career guidance manuals.

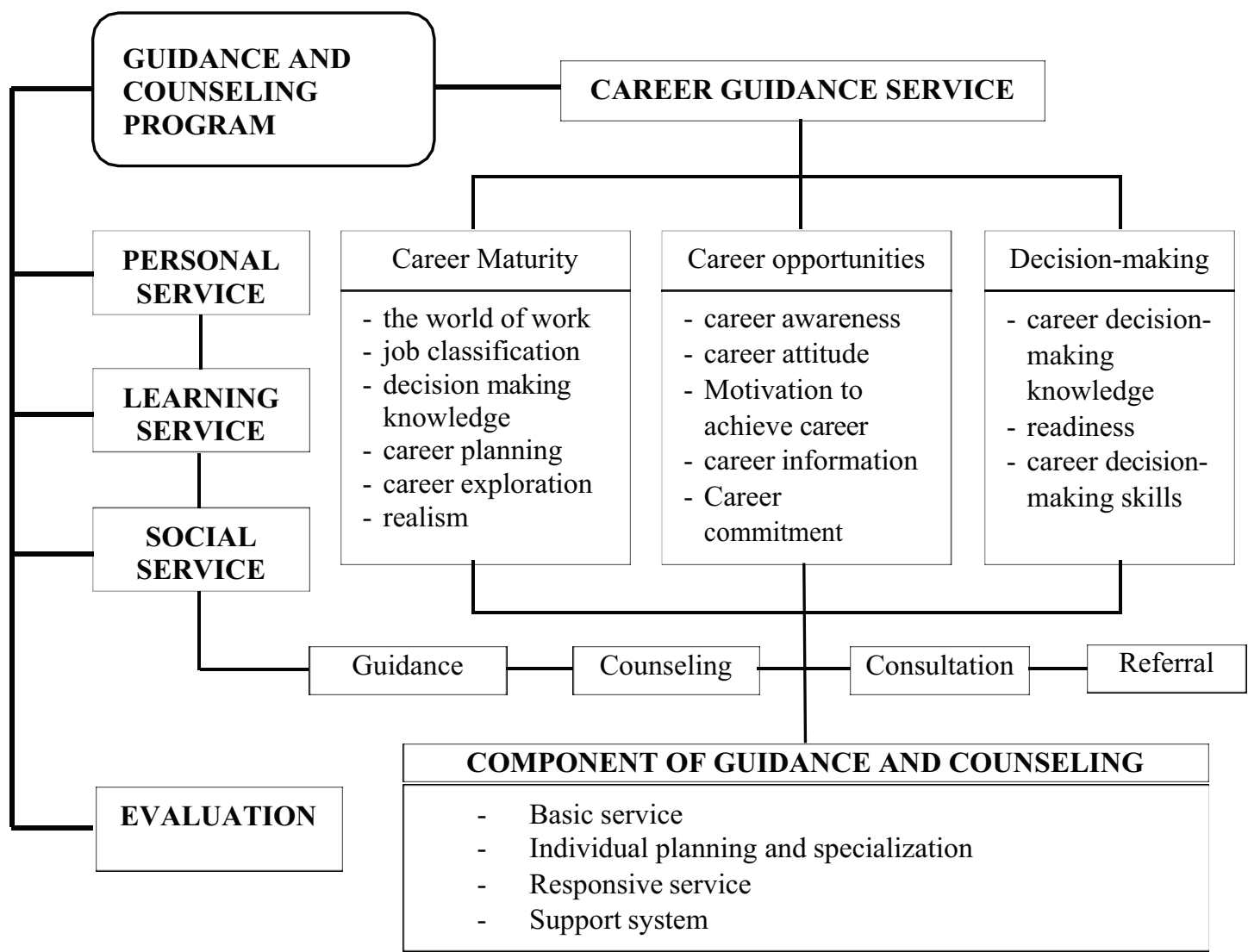

Figure 1: Model of Career Guidance in Indonesian VHS.

\subsection{Career maturity development service}

This career maturity service is an effort to facilitate the development of students" career maturity which is the readiness to make the right career decisions. Two dimensions developed the cognitive and non-cognitive aspects. The cognitive size consists of (1) the world of work information, (2) knowledge of the preferred occupational group, and (3) decision-making knowledge. While non- cognitive dimension consists of (1) career planning, (2) career exploration, and (3) realism. Thus, a career maturity development service is an activity to facilitate the development of these six aspects.

The knowledge of the world of work is an all information about it. It is encompassed in five aspects of it about the way people who have a career that are: learn the job, understand the interests and abilities, requirements to enter a job, tasks of some jobs, and reasons for other people to change or move jobs. Meanwhile, the knowledge 
of more desirable world of work is covered in five aspects: job tasks, equipment or equipment needed, physical requirements, identification of reasons for choosing a job, and risks that may arise from the occupational field.

Career planning is the activity of making future career plans which discussing it with a counselor by facilitation. Career exploration is the students" activity to utilize parents, teachers, counselors, career experts, books, or other relevant sources as career information sources. Its importance is to have a complete career information. Realism is a commitment to choosing a realistic career, which takes into account objective conditions of self-characteristics, opportunities, and environmental demands.

\subsection{Career opportunities service}

Career opportunity analysis services is the guidance seeks to facilitate the analysis of opportunities for careers. There are four aspects of ability to analyze career opportunities, namely (1) career awareness, (2) career attitudes, (3) career motives, and (4) career commitment. Career awareness is the process of curiosity and excitement in the career field and growing confidence in career opportunities. This awareness indicator are the frequency of students inquiring about different career areas, time, and the number of career resources explored. Career attitudes are the direction of the student's tendency towards the interest career field. To appear positive attitude of the student to the career can be held by appreciation, inspiration and positive activity to the career interest. Achievement motive is the drive to achieve something as possible. Characteristics of students to with high motivation are having strong desire, responsible, and not wasting career opportunities that exist.

Career opportunities information is the variety of information about job opportunities. Activities that can be developed are (1) job market, (b) career days, and (3) career visit. Career commitment is the students" determination to the future career. The characteristics of students having the career commitment are (1) have strong beliefs, (2) seek and choose relevant activities, (3) be serious in carrying out activities related to their career field, (4) responsible for the risks of career decisions and (5) career interest tends to persist.

\subsection{Career decision-making service}

Career decisions are the process of determining career choices. This ability is based on students' knowledge, readiness, and skills. The underlying knowledge is the knowledge 
of life purpose, self, environment, values, the world of work, and knowledge of career decisions. Readiness to make career decisions is the ability and the confidence to make career choices. To build belief can be done through group and individual guidance. The knowledge of career decisions making is a cognitive domain. The readiness is an affective domain. Then, the skills of career decisions making is an action. Therefore, students who be able in making an action means that they have a sense of responsibility that is aware of risks and live career decisions in earnest.

\section{Discussion}

Career guidance developed in various countries has implied to the practical level. In Indonesian education, the three notions of educational, career, and vocational guidance are likely to be unity and renowned as guidance and counseling. The unification of these three ideas imply for its concept and practice to be vague. Conceptually, there is no distinction prior principle between educational and vocational guidance. Practically, career guidance becomes unpopular among students because typically to whom handled by counselors are those troublemakers. This indistinct cannot be separated from the facts that guidance and counseling in schools dealing more with personal, learning and social issues.

Based on the official manuals setting out by $\mathrm{MoEC}$, there is no significant difference in career guidance practices between general and vocational education. Government and practitioners have a tendency to equalize the functions of career guidance in general and vocational education. It implies that career guidance in vocational education does not require specificity as the distinctive characteristics of vocational education. This understanding is not congenial to the Miller's concept that guidance is a crucial component of vocational education (Miller, 1984). Thus, the vocational education oriented to the world of work is not redounded by the proper career guidance concept. This incompatibility becomes the shortage of career guidance in VHS which affects to the students" development. Empirical study suggests that the shortage of career guidance may bring some problems about limited information on career, low effort in finding information about career, lack of career vision and self-exploration and career choice finding difficulties [5].

Meanwhile, the standard of student achievement in career guidance called the learners' self- reliance competency standard (LSCS) has not be standardize by the legal authority. It is chiefly based on the provision of professional association's guidance and counseling. This provision has not been legalized into any government regulation 
so far. The non-stipulation of LSCS into legal standards through ministerial regulation shows that the government is likely to be more attention shortage to career guidance. The absence of standards may cause the career guidance achievement criteria difficult to be measured. In practice so far, measuring the counselors' performance is the sole of the success criteria. However, the students" achievement in the LSCS has not been a significant concern. For VHS students, this LSCS must be distinguished from the characteristic of GHS. From the eleven of developmental aspects of LSCS, VHS students should be prioritized on strengthening self- development, entrepreneurial behavior, career insight, and readiness aspects. The conditions and demands of the world of work continuing to change over times, therefore, the career guidance in VHS should also be directed to strengthening the current trend of skills and attitudes.

Based on VHS career guidance model described in the previous session, those activities focus more on three aspects of career maturity, career opportunities, and career decision making. However, if analyzing more thoroughly from these three elements, the model has not illustrated the other crucial elements of vocational education such as: employability skills and entrepreneurship development. Because VHS graduates have three career paths: continuing education in the academic track, work or take the transition through further training, and entrepreneur or self-employed, the career guidance service should also be pointed to these three paths.

The idea of career guidance in VHS should be more emphasized on the vocational guidance model. This concept has the series of steps: individual data inventory, occupational information, counseling, placement, follow up and evaluation [7]. Therefore, strategy to succeed career guidance in VHS is not solely by conducting the primary service but also providing the career education and training. It means that career guidance is beneficial for the individual to be aware of self-potential and career decision making, even help individual to enhance the skills needed by the world of work. This concept is relevant to two principles of career guidance within VET program described by Watt. Firstly, career guidance should be available at all relevant decision points, and on exit. Secondly, career education program has a significant role to play both preparing students for future career and supporting the transferability of their learning [9].

Analysis the needs of career guidance can be considered on the three roles of effective career guidance in VHS. The first part, preparing individuals who have career maturity. It can be done through a series activities of vocational maturity development and career decision making. The second, preparing the skills demanded by the world of work. This activity can be held by analyzing the latest skill trends and passing skill 
development through training. The third is connecting labor market to fulfil supply and demand. The third role will be achieved by improving collaboration and relationships with internal and external schools. The present model is insufficient for career guidance in VHS on the second and third parts.

Although the author looks the existing career guidance model in vocational schools on the weaknesses view point, the practitioners or others may allege reasonable option model. This hypothesis model is untested through a vast and thorough study, therefore the further investigation on developing skills model of career guidance program in vocational education fields is necessary to promote this analysis.

\section{Conclusion}

This review provides early understanding the notion and the tradition of career guidance in the Indonesian VHS. Career guidance is one of four aspects of guidance and counseling in Indonesian education system. There is no significant differences between guidance and counseling program in VHS and GHS. Meanwhile, all theories are agree that the characteristics of vocational education is dissimilar by the general education. It should be noted that career guidance should contribute vocational education programs to obtain graduates who well-prepared to work.

The small portion, weak in LSCS legality, and lack of conformity with the characteristics of vocational education what are meant by the career guidance shortages. The small portion is caused by dealing more guidance and counseling activities to personal, learning and social issues. The absence of LSCS standard is become ambiguous to its practice. Obviously, the vagueness of career guidance in vocational education will maintain the typical tradition as well as in the general education. It implies that the practitioners and governments should seriously consider fulfilling VHS students demand to the career guidance.

The revitalization of VHS, trends in the present labor market and skills, and career choice flexibility of VHS graduates are having relevance to the need of specific career guidance. The revitalization means that VHS should focus on developing employability skills for a job. The change of labor market trends and the company expectation to their employees" abilities lead the significant role of career guidance. The existing career guidance model focused on three aspects of career maturity, opportunities and decision making has not sufficient enough for student to develop their employability skills and entrepreneurship so far. The effective career guidance in VHS is not merely 
by conducting the basic career service but also by providing the career education and training simultaneously in developing employability skills.

\section{Funding}

This work was supported by the Doctoral Dissertation Research of the Ministry of Research, Technology and Higher Education under Grant No. 069/SP2H/LT/DRPM/2018 in Year 2018.

\section{Acknowledgement}

The authors would like to thank their colleagues for their contribution and support to the research. They are also thankful to all the reviewers who gave their valuable inputs to the manuscript and helped in completing the paper.

\section{Conflict of Interest}

The authors have no conflict of interest to declare.

\section{References}

[1] Central Bureau of Statistics. (2015). Survei Angkatan Kerja Nasional (Sakernas) 2004 - 2014. Retrieved on May 2015 at http://www.bps.go.id.

[2] Hooft, E. A. V., Born, M. P., Taris, T. W., FLIER, H. V. D., \& Blonk, R. W. (2004). Predictors of job search behavior among employed and unemployed people. Personnel Psychology, vol. 57 (1), pp. 25-59.

[3] Köhler, T. \& Börner, C. (2007). Development of a cooperative online communication infrastructure for career guidance experts; In: Career guidance - A European dimension; Athens, University Press.

[4] Köhler, T., Härtel, L. \& Federow S. (2015). Datenreport 2014. Kompletterfassung und zielgruppengerechte Darstellung aktueller bzw. regelmäßiger Projekte, Maßnahmen, Initiativen und Akteure der Berufs- und Studienorientierung in der Landeshauptstadt Dresden. (2014). Online: https://www.dresden.de/media/pdf/ wirtschaft/broschueren/KoBOSTO_Datenreport_2014.pdf.

[5] Tarigan, M., \& Wimbarti, S. (2011). Career Planning Program to Increase Career Search Self Efficacy in Fresh Graduates. Journal of Higher Education Theory and Practice, 
vol. 11 (4), pp.75.

[6] Sears, S. (1982). A Definition of Career Guidance Terms: A National Vocational Guidance Association Perspective. Vocational Guidance Quarterly, 31(2), 137-143. doi: 10.1002/j.2164- 585X.1982.tb01305.x.

[7] London, H. H. (1973). Principles and Techniques of Vocational Guidance. Columbus, Ohio: Charles E. Merrill Publishing Co.

[8] Miller, M. D. (1984). Principles and a Philosophy for Vocational Education. Special Publication Series No. 48. Retrived on November 2017 at https://files.eric.ed.gov/ fulltext/ED250497.pdf.

[9] Watts, A. G. (2009). The Relationship of Career Guidance to VET (Background document for the OECD reviews of vocational education and training). Paris: OECD.

[10] Bogluț, A., Rizeanu, S., \& Burtăverde, V. (2015). Vocational Guidance for Undergraduate Psychology Students. Psychometric Properties of the Questionnaire of Vocational Interests in Psychology. Procedia - Social and Behavioral Sciences, 187, 713-718. doi: http://dx.doi.org/10.1016/j.sbspro.2015.03.133.

[11] Watts, A. G., Dartois, C., \& Plant, P. (1987). Careers guidance services within the European Community: contrasts and common trends. International Journal for the Advancement of Counseling, 10(3), 179-189. doi: 10.1007/bf00115701.

[12] Company, Federich J. (2009). Vocational Guidance and Career Counseling in the European Union: Origins and Recent Trends. In Maclean, Rupert (eds). International Handbook of Education for the Changing World of Work: Bridging Academic and Vocational Learning. UNESCO-UNEVOC International Centre for Technical and Vocational Education, Bonn, Germany: Springer.

[13] Bußhoff, L., \& Heller, K. A. (1988). Educational and Vocational Guidance Services for the 14-25 Age Group in the Federal Republic of Germany. www.epub.ub.unimuenchen.de

[14] Zelloth, H. (2014). Technical and Vocational Education and Training (TVET) and Career Guidance: The Interface. In G. Arulmani, J. A. Bakshi, L. F. T. Leong \& G. A. Watts (Eds.), Handbook of Career Development: International Perspectives (pp. 271-290). New York, NY: Springer New York.

[15] President of Indonesia. (2016). Instruksi Presiden Nomor 9 Tahun 2016 tentang Revitalisasi Sekolah Menengah Kejuruan. Jakarta: Sekretariat Negara.

[16] Kumar, S. \& Arulmani, G. (2014). Understanding the Labor Market: Implications for Career Counseling. In G. Arulmani, J. A. Bakshi, L. F. T. Leong \& G. A. Watts (Eds.), Handbook of Career Development: International Perspectives (pp. 271-290). New York, NY: Springer New York. 
[17] Finch, C. R., \& Crunkilton, J. R. (1999). Curriculum Development in Vocational and Technical Education: Planning, Content, and Implementation. Massachusset: Allyn and Bacon.

[18] Trilling, B., \& Fadel, C. (2009). 21st Century Skills: Learning for Life in Our Times. California: John Wiley \& Sons, Inc.

[19] Ismail, S., \& Mohammed, D. S. (2015). Employability Skills in TVET Curriculum in Nigeria Federal Universities of Technology. Procedia-Social and Behavioral Sciences, 204, 73-80.

[20] Guerts, J., \& Meijers, F. (2009). Vocational Education in the Netherlands: In Search of a New Identity. In R. Maclean \& D. Wilson (Eds.), International Handbook of Education for the Changing World of Work (pp. 483-497). Bonn, Germany: Springer Science+Business Media B.V.

[21] MoEC. (2016). Panduan Operasional Penyelenggaraan Bimbingan dan Konseling Sekolah Menengah Kejuruan (SMK). Jakarta: Kemendikbud.

[22] MoEC. (2014). Peraturan Menteri Pendidikan dan Kebudayaan Nomor 111 Tahun 2014 tentang Bimbingan dan Konseling pada Pendidikan Dasar dan Menengah. Jakarta: Kemendikbud. 